\title{
PETROLOGY AND GEOCHEMISTRY OF A U AND TH ENRICHED NEPHELINITE FROM MT. NYIRAGONGO, ZAIRE: ITS BEARING ON ANCIENT MANTLE METASOMATISM
}

\author{
R. VOLLMER; P. H. NIXON and E. CONDLIFFE
}

\begin{abstract}
VOLLMER, R.; NIXON, P. H. and CONDLIFFE, E., 1985: Petrology and geochemistry of a $U$ and Th enriched nephelinite from Mt. Nyiragongo, Zaire: Its bearing on ancient mantle metasomatism. Bull. Geol. Soc. Finland 57, Part 1-2, $37-46$.

Unusual large $\mathrm{Pb}$ isotope variations found by Vollmer and Norry (1983 a) in nephelinites from Nyiragongo and related volcanoes date a $500 \mathrm{Myr}$ old U(Th)/ $\mathrm{Pb}$ fractionation. $\mathrm{U}-\mathrm{Th}-\mathrm{Pb}$ systematics suggest that $\mathrm{U}, \mathrm{Th}$ and radiogenic $\mathrm{Pb}$ are concentrated in an accessory xenocryst phase. We undertook a detailed mineralogical and chemical study of rock $\mathrm{C} 9872$, which is characterised by extreme radiogenic $\mathrm{Pb}$ isotope abundances, but did not find such xenolithic phase. Major element abundances of $\mathrm{C} 9872$ are close to average Nyiragongo nephelinite compositions. Among minor elements only $\mathrm{Th}$ and $\mathrm{U}$ are exceptionally enriched by an order of magnitude. Neither melilite nor perovskite were observed in C 9872 . Melilite may have broken down to a calcium bearing fayalite during late stage $\mathrm{Fe}$ metasomatism (Sahama 1961, 1978). Possible U and Th hosts include minerals normally associated with carbonatites such as perovskite or pyrochlore. However, either these phases remained undetected or were broken down during Fe metasomatism, although the undisturbed $\mathrm{U}-\mathrm{Th}-\mathrm{Pb}$ systematics imply that none of these elements were added or lost in this process. We propose that $\mathrm{U}$ and $\mathrm{Th}$ bearing minerals from a $500 \mathrm{Myr}$ old carbonatite or carbonatite precursor (metasomatised mantle?) were incorporated into the nephelinite magma.
\end{abstract}

Key words: nephelinites, carbonatites, Nyiragongo, East African rift volcanism, $\mathrm{Pb}$ isotopes, $\mathrm{U}-\mathrm{Th}-\mathrm{REE}$ geochemistry, mantle metasomatism.

R. Vollmer; P. H. Nixon and E. Condliffe: Department of Earth Sciences, The University, Leeds LS2 9JT, England.

\section{Introduction}

Heterogeneous enrichment of the subcontinental mantle in lithophile (LIL) elements by metasomatising fluids is increasingly regarded to be a precursor to alkaline volcanism (e.g. Lloyd and Bailey 1975; Menzies and Murthy 1980; Wass and Rogers 1980; Bailey 1982; Men- zies et al. 1983; Chauvel and Jahn 1984). However, little is known about the time relationship of metasomatism to volcanism. Upward migration of volatiles may provide not only the means of chemical enrichment of the mantle but also the trigger of igneous activity (Bailey 1980, 1982). Nd and $\mathrm{Sr}$ isotope data from nodules suggest that LIL element enrichment may be 
contemporaneous with volcanism in some cases but be in others a much earlier event (Menzies and Murthy 1980; Erlank et al. 1982). It seems, that it has only once so far been possible to date a metasomatic event in the mantle fairly precisely. Vollmer and Norry (1983 a) found unusually large $\mathrm{Pb}$ isotopic variations in nephelinites from Mt. Nyiragongo, Zaire. Although these authors were unable to dismiss the possibility that the $\mathrm{Pb}$ isotopic variations were caused by crustal contamination, they favoured the interpretation that these isotopic compositions are representative of the magma sources in the mantle and date a $484 \pm 28(2 \sigma)$ Myr old metasomatic event which caused variable and, in one case, extreme fractionation of $\mathrm{U} / \mathrm{Pb}$ and $\mathrm{Th} / \mathrm{Pb}$. Assuming their inferences to be valid, it would define mantle metasomatism in this area as an old event and probably only of some tens of million years duration rather than a continuing process as suggested by Bailey (1977).

The model would have further and more general implications: (i) Alkaline volcanism could here not be directly caused by rising mantle diapirs as suggested e.g. by Morgan (1971) and Allègre et al. (1981) for alkaline volcanism generally. Partial melting would rather be a response to decompression and rising geotherms during rifting and thinning of the lithosphere and may be initiated preferentially within metasomatised mantle domains (Vollmer and Norry 1983 b).

(ii) The $\mathrm{U}(\mathrm{Th}) / \mathrm{Pb}$ fractionation patterns inferred for metasomatism of the Nyiragongo source could then possibly also provide an answer to the more complex evolution of the $\mathrm{U}-\mathrm{Pb}$ decay system relative to the $\mathrm{Sm}-\mathrm{Nd}$ and $\mathrm{Rb}-\mathrm{Sr}$ systems which is suggested by the $\mathrm{Pb}, \mathrm{Nd}$ and $\mathrm{Sr}$ isotopic features of oceanic basalts (Vollmer 1983).

To investigate further the question of mantle metasomatism versus crustal contamination for Nyiragongo magmas we present here a detailed mineralogical and chemical analysis of one rock, C9872, for which extreme radiogenic $\mathrm{Pb}$ isotopic compositions were observed.

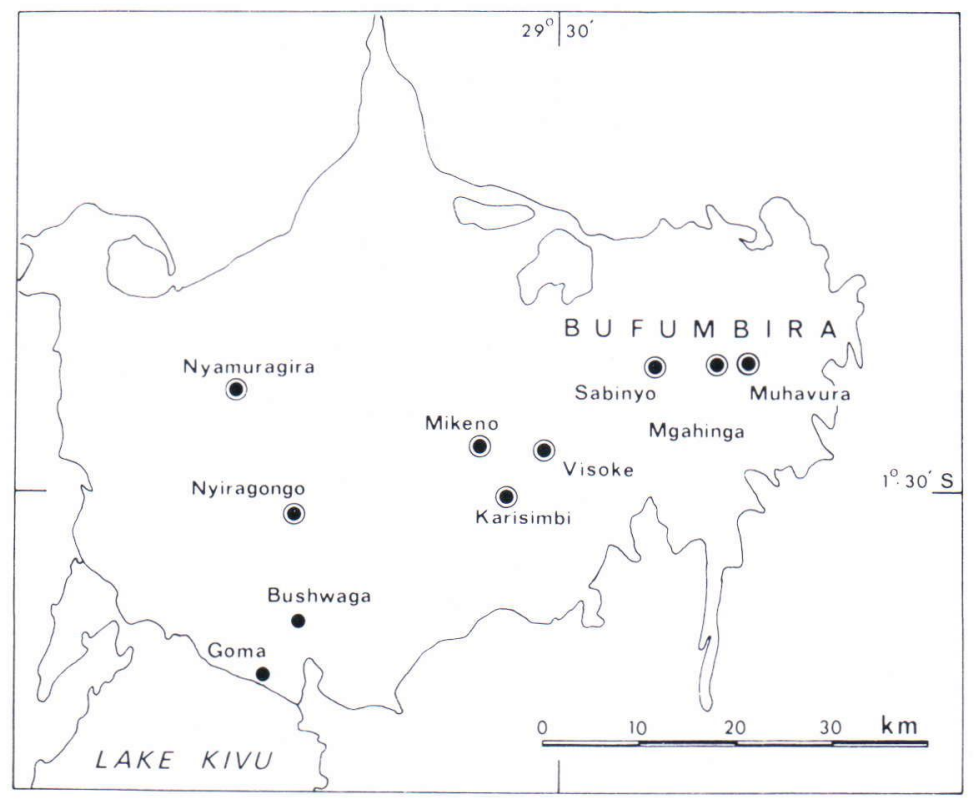

Fig. 1. The Late Pliocene to historic Virunga volcanic field in the western branch of the East African rift. 
Fig. 2. $\mathrm{Pb}$ isotopic compositions of Nyiragongo and related cones of Bushwaga and Goma. The fields denote the range of mantle $\mathrm{Pb}$ isotopic variations as defined by oceanic basalts. ${ }^{206} \mathrm{~Pb} /{ }^{204} \mathrm{~Pb}$ variations are the largest ever observed for young volcanic rocks and date a ca. 500 Myr old U(Th)/Pb fractionation event. Data from Vollmer and Norry (1983 a).
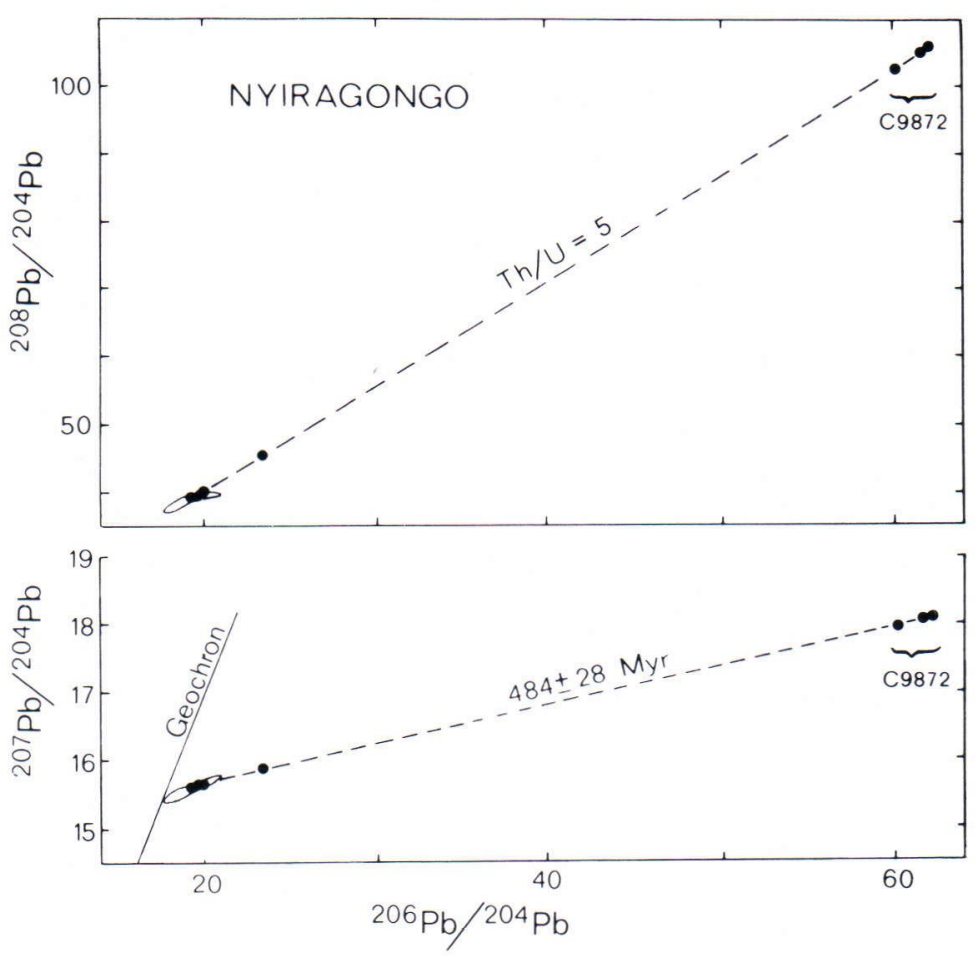

\section{Nyiragongo $\mathbf{P b}$ isotopic variations}

The Virunga volcanic field (Fig. 1) lies within the western branch of the East African rift system. Melilite- and leucite-nephelinites from Nyiragongo (Sahama 1978) and associated small volcanoes (Bushwaga and Goma among others) are petrographically distinct from other Virunga volcanic rocks which vary from leucitites, leucite-bearing tephrites and phonolites to latites (Holmes and Harwood 1937).

$\mathrm{Pb}$ isotope data for Nyiragongo and associated nephelinite volcanoes are compared in Fig. 2 with the range of mantle variations as defined by oceanic basalts. The three extreme radiogenic points are triplicate sample dissolutions of $\sim 100 \mathrm{mg}$ fractions taken from a powdered sample of rock C9872. The measurements are distinct and outside the analytical uncertainty, indicating heterogeneities in the powdered sample. The lava is not in isotopic equilibrium on a handspecimen scale. This is uncommon for young volcanic rocks, but does not seem to be exceptional for Nyiragongo lavas: Two other samples (C9958, C3022) are also heterogeneous in their $\mathrm{Pb}$ isotopic compositions (see Table 2 in Vollmer and Norry, 1983 a). This suggests that the radiogenic $\mathrm{Pb}$ and by inference the radioactive parent elements $U$ and $T h$ are concentrated in an accessory xenolithic phase which failed to equilibrate with the melt. The same conclusion can be reached from the $\mathrm{U}-\mathrm{Pb}$ isochron diagram (Fig. 3). The measured $\mu$-value $\left({ }^{238} \mathrm{U} /{ }^{204} \mathrm{~Pb}\right)$ of sample C9872 is consistent with the $\Delta^{207} \mathrm{~Pb} /$ $\Delta^{206} \mathrm{~Pb}$ age of $484 \mathrm{Myr}$ and an estimate of the initial ${ }^{206} \mathrm{~Pb} /{ }^{204} \mathrm{~Pb}$ ratio derived from the least radiogenic samples (Fig. 3). In other words, the $\mathrm{U} / \mathrm{Pb}$ ratio of sample $\mathrm{C} 9872$ is identical with the source $\mathrm{U} / \mathrm{Pb}$ ratio. The agreement is unlikely to be fortuitous because the measured $\mathrm{Th} / \mathrm{U}$ ratio of 4.9 (Table 2) is also identical with source $\mathrm{Th} / \mathrm{U}=5.0$ inferred from the $\mathrm{Pb}$ isotopic ra- 
tios. $\mathrm{U}-\mathrm{Th}-\mathrm{Pb}$ has not been fractionated either by partial melting or by subsequent processes such as fractional crystallization, gaseous transfer in the volcanic conduits or leaching and redeposition of $\mathrm{U}$. The results are probably consistent only with the $\mathrm{U}, \mathrm{Th}$ and radiogenic $\mathrm{Pb}$ in the rock being concentrated in accessory xenocrysts. It should be noted that the other two samples for which $\mathrm{U}$ and $\mathrm{Pb}$ concentrations were reported (Table 2, Vollmer and Norry 1983 a) have $\mathrm{U} / \mathrm{Pb}$ ratios in excess of inferred source ratios (Fig. 3) implying $\mathrm{U}$ gain or $\mathrm{Pb}$ loss (less likely because $\mathrm{Pb}$ is not unusually low) during the volcanic activity.
Vollmer and Norry (1983 a) discussed whether crustal contamination or a mantle enrichment event is responsible for the extreme $\mathrm{Pb}$ isotopic compositions. Common crustal rocks are unsuitable as a contaminant as the radiogenic $\mathrm{Pb}$ of $\mathrm{C} 9872$ could only have developed in $\sim 500$ Myr old $U$ and Th mineralization. Mineralizations associated with 500-600 Myr old granites are found to the north-east of Virunga (Cahen 1970). Clearly, the possibility of contamination cannot be lightly dismissed.

Against a crustal origin of the $\mathrm{U}$ and $\mathrm{Th}$ rich xenocrysts is that all analysed Nyiragongo rocks but none of the associated Virunga potas-

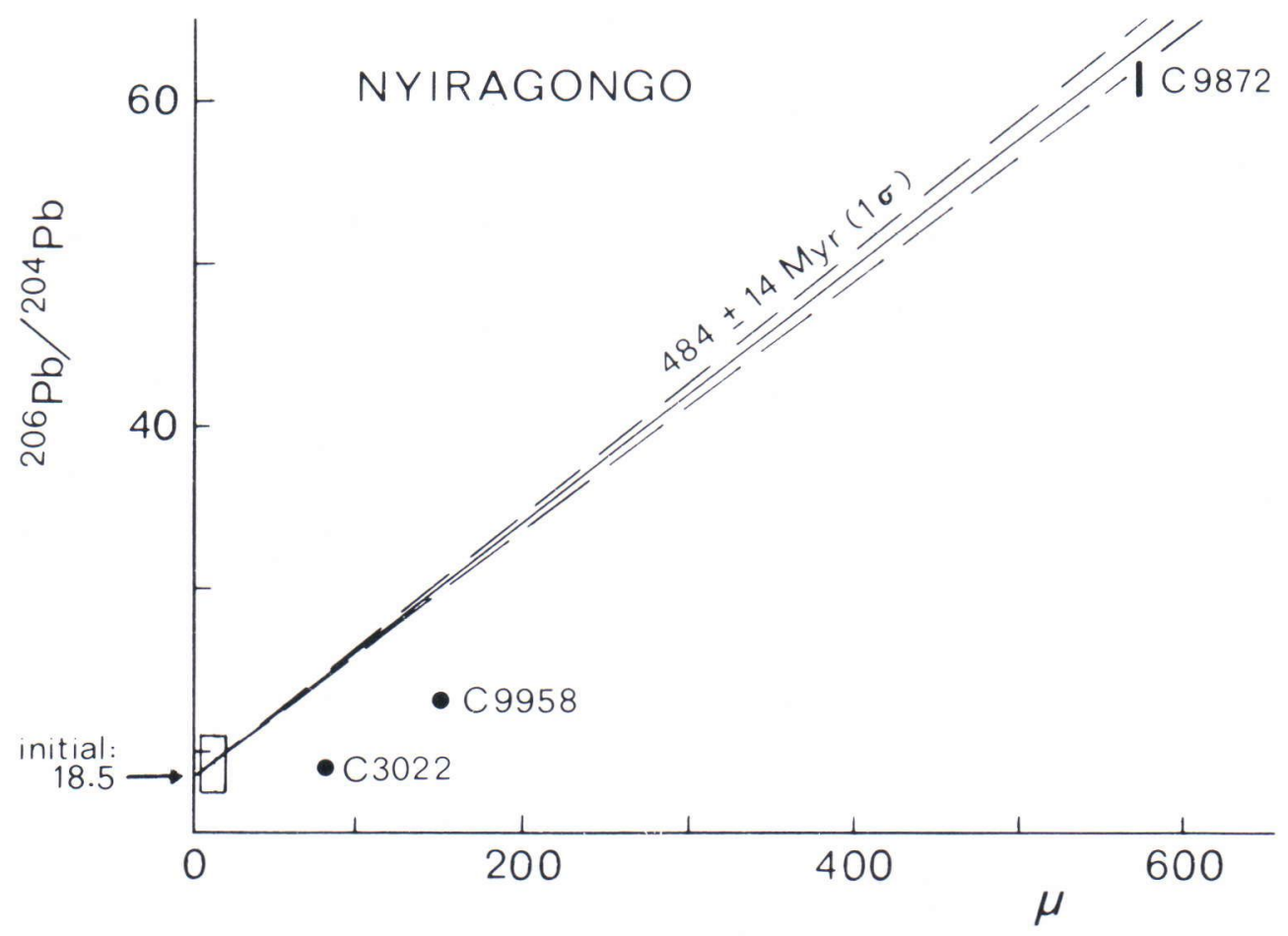

Fig. 3. ${ }^{206} \mathrm{~Pb} /{ }^{204} \mathrm{~Pb}$ versus ${ }^{238} \mathrm{U} /{ }^{204} \mathrm{~Pb}(\mu)$ for nephelinites from Nyiragongo and associated cones. Oceanic basalts generally plot within the box, but much of the observed variations in $\mu(5-20)$ are due to late-stage $\mathrm{U} / \mathrm{Pb}$ fractionation accompanying volcanism; oceanic basalt mantle source variations are estimated to be within $\mu=9 \pm 3$ (Tatsumoto 1978). This estimate is used in conjunction with the least radiogenic $\mathrm{Pb}$ observed for Nyiragongo rocks to constrain the initial value of the 484 Myr reference isochron to ${ }^{206} \mathrm{~Pb} /{ }^{204} \mathrm{~Pb}=18.5$. The age of this reference isochron is derived from Fig. 2 . ${ }^{238} \mathrm{U} /{ }^{204} \mathrm{~Pb}(\mu)$ for rocks C9958 and C3022 has been strongly fractionated at some time during partial melting or the volcanic activity, probably by $\mathrm{U}$ gain as $\mathrm{Pb}$ concentrations are high. By contrast, $\mu$ for $\mathrm{C} 9872$ could not have been significantly fractionated; the measured value is still representative of $\mu$ in the source region for this magma batch. Although $\mathrm{Pb}$ and $\mathrm{U}$ are both $h y g$-elements and partition into the melt fraction during partial melting, lack of fractionation points to $\mathrm{U}$ and $\mathrm{Pb}$ being concentrated in an accessory xenolithic phase. The same is true for Th (see text). Data from Vollmer and Norry (1983 a). 
sic volcanic rocks fall on the $\mathrm{Pb}-\mathrm{Pb}$ isochrons (which are also two-component mixing lines with normal mantle compositions and radiogenic xenocrysts as end-members (Fig. 2; see also Fig. 1 in Vollmer and Norry 1983 a). A crustal origin of the xenocrysts would not explain why only nephelinitic magmas from Nyiragongo and associated centres should have incorporated them. This observation however, could reasonably be explained if these xenocrysts were carried up by the Nyiragongo magmas from a deeper (mantle) source. The $\mathrm{Pb}, \mathrm{Nd}$ and $\mathrm{Sr}$ isotope signatures and very different chemistries of the Virunga potassic magmas exclude their derivation from the same source as
Nyiragongo nephelinites (Vollmer and Norry 1983 b). If these authors are correct in their suggestion that the sources for the Virunga potassic magmas lie at shallower levels than the Nyiragongo source, then these magmas would not be able to pick up the $\mathrm{U}$, Th and radiogenic $\mathrm{Pb}$ carrying xenocrysts. Alternatively, the lateral extension of the Nyiragongo source could be limited towards the north and north-east to $\sim 10 \mathrm{~km}$ (Fig. 1).

\section{Nephelinite C9872}

The single rock examined here is a grey finegrained vesicular leucite-nephelinite, C9872,

Table 1. Rock and mineral analyses of leucite nephelinite, C9872, from Goma, Virunga volcanic field.

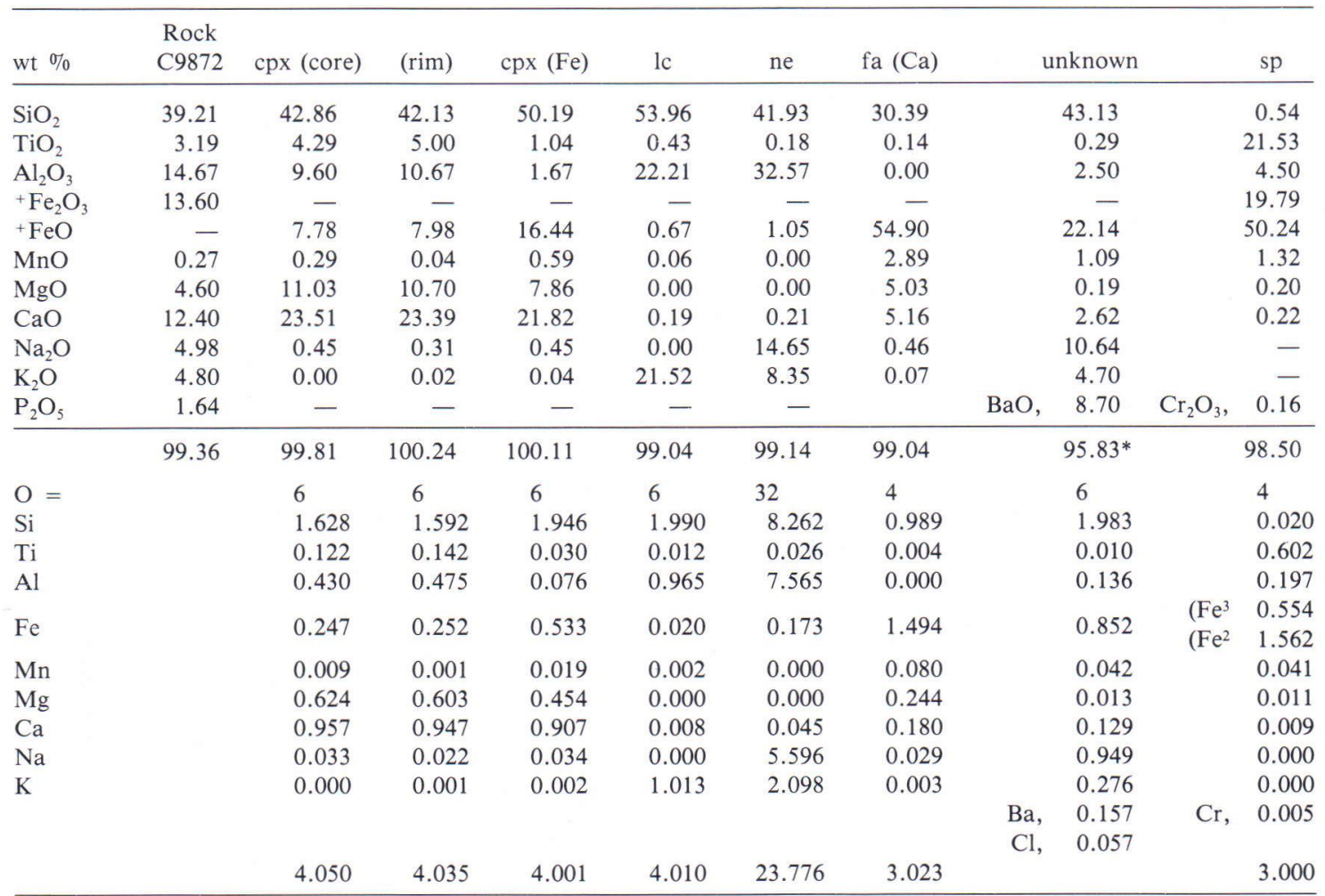

+ Total Fe is iron oxide except for spinel where analysis is adjusted, assuming stoichiometry (see text)

* includes $\mathrm{Cl}, 0.73 ; \mathrm{S}$ also present

Rock analysis by X.R.F. (analyst: A. Grey); for minor elements see text

Mineral analyses by electron microprobe (analyst: E. Condliffe)

Abbreviations: cpx, clinopyroxene; lc, leucite; ne, nepheline; sp, spinel 
from the collection of the University of Cambridge. It had been collected by A. D. Combe from Goma, or Ngoma, a small volcano near the north shore of Lake Kivu some $17 \mathrm{~km}$ south of the related main volcano of Nyiragongo (Fig. 1). It contains sporadic clinopyroxene phenocrysts up to $5 \mathrm{~mm}$ long. Spinel (magnetite) is common as microphenocrysts and granules in the matrix which is largely made up of diffuse areas of clear nepheline and equant leucite. Apatite is present as occasional coarse crystals cored with inclusions and as fine spicules in the groundmass. Accessory olivine and an unknown barium mineral occur. A $1 \mathrm{~cm}$ lava xenolith of similar mineralogy but slightly coarser than the enclosing lava was noted.

An analysis (Tables 1,2) was carried out on the rock powder used in the isotope study of Vollmer and Norry (1983 a). The major element levels are similar to those of lavas from the Nyiragongo field, including Goma, previously determined by Sahama and others, e.g. in Bell and Powell (1969). They illustrate the highly undersaturated feldspathoidal nature of the rocks which is unique to the Virunga field and which is not represented in the volcanic area to the east - the Bufumbira volcanics (Holmes and Harwood, 1937, p. 233). The abundance of nepheline is shown by the high $\mathrm{Na}_{2} \mathrm{O}$ values which ap-

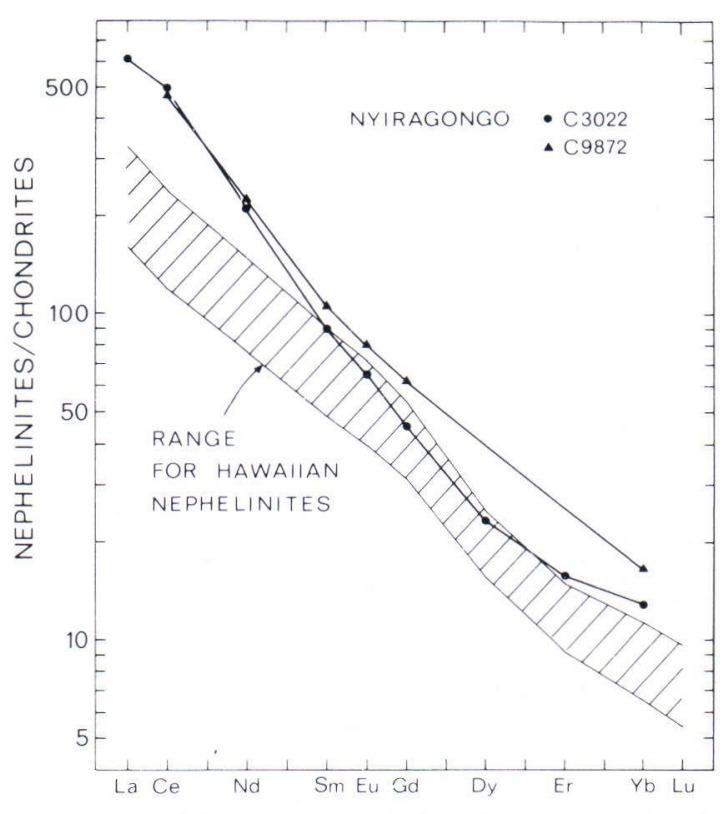

Fig. 4. Chondrite normalized REE abundances of leucitenephelinite C 9872 and melilite-nephelinite C3022 from Nyiragongo compared to Hawaiian nephelinites (Kay and Gast 1973; Clague and Frey 1982). Nephelinites from south eastern Australia (Frey et al. 1978) fall also within this range. Data: this work and R. V. unpublished.

proach and even exceed (Table 1) those of $\mathrm{K}_{2} \mathrm{O}$ contrasting with the high $\mathrm{K}_{2} \mathrm{O} / \mathrm{Na}_{2} \mathrm{O}$ ratios seen in Bufumbira where nepheline is comparatively rare. The combination of low silica with low

Table 2. Trace element abundances (in ppm) for leucite-nephelinite C9872 from Goma, Virunga.

\begin{tabular}{|c|c|c|c|c|c|c|c|c|c|c|c|}
\hline & $\mathrm{a}$ & b & & a & b & c & & $\mathrm{d}$ & & $\mathrm{a}$ & e \\
\hline $\mathrm{Sc}$ & 16 & & $\mathrm{Rb}$ & 100 & 130 & 110 & $\mathrm{La}$ & 174 & $\mathrm{~Pb}^{t}$ & & 14.0 \\
\hline V & 272 & & $\mathrm{Sr}$ & 1868 & 2228 & 2421 & $\mathrm{Ce}$ & 383 & $\mathrm{~Pb}^{\mathrm{c}}$ & & 5.6 \\
\hline $\mathrm{Cr}$ & 2 & 4 & Y & 33 & 34 & & $\mathrm{Nd}$ & 134.6 & Th & 245 & \\
\hline $\mathrm{Co}$ & 38 & 34 & $\mathrm{Zr}$ & 214 & 234 & 634 & $\mathrm{Sm}$ & 20.45 & $\mathrm{U}$ & & 50.3 \\
\hline $\mathrm{Ni}$ & 23 & 42 & $\mathrm{Nb}$ & 192 & 156 & 117 & $\mathrm{Eu}$ & 5.80 & & & \\
\hline $\mathrm{Cu}$ & 91 & 178 & $\mathrm{Ba}$ & & 1781 & & $\mathrm{Gd}$ & 14.9 & & & \\
\hline $\mathrm{Zn}$ & 108 & 104 & & & & & $\mathrm{Yb}$ & 3.6 & & & \\
\hline
\end{tabular}

a by XRF, analyst A. Grey, University of Leeds

${ }^{b}$ by XRF, University of Bochum, H.-U. Schmincke, pers. communication

c by XRF, from Bell and Powell (1969)

${ }^{d}$ by ID but inferior analysis; errors: Ce, Nd, Sm, Eu: $\pm 1 \%$; Gd: $\pm 2 \%$; La, Yb: $\pm 5 \%$

c by ID, from Vollmer and Norry (1983 a)

a, b, d, e: aliquot analyses of the same rock powder

$\mathrm{Pb}^{\text {t}}$ : total $\mathrm{Pb}$ (common and radiogenic $\mathrm{Pb}$ produced in situ through $\mathrm{U}$ and $\mathrm{Th}$ decay)

$\mathrm{Pb}^{\mathrm{c}}$ : common $\mathrm{Pb}$ 
magnesia is typical of the Nyiragongo field.

Trace element abundances are listed in Table 2. $\mathrm{Zr}$ concentrations reported by Bell and Powell (1969) are probably too high. Other discrepancies could possibly be due to sample heterogeneity. REE abundances in C9872 and a melilite-nephelinite (C3022) from Nyiragongo are similar (Fig. 4). Both rocks are more strongly enriched in the LREE than most primary nephelinites from oceanic and continental regions. The concave upwards patterns suggests residual clinopyroxene and/or clinopyroxene fractionation (Irving 1978). Nephelinite C3022. has a small positive $\mathrm{Eu}$ anomaly $\left(\mathrm{Eu} / \mathrm{Eu}^{*}=\right.$ 1.02 ) as is observed in most alkali-basalts and nephelinites for which precise analyses are available (Kay and Gast 1973; Sun and Hanson 1975).

Magmatophile (hyg) elements normalized to primitive mantle abundances (Wood et al. 1979) are plotted in Fig. 5 for C9872 and a nephe- line-leucitite from Nyiragongo and, for comparison, a nephelinite from Hawaii (Clague and Frey 1982). The extreme enrichment of $U$ and Th in C9872 is immediately apparent. Large $\mathrm{Zr}$ differences between the two Nyiragongo samples could be due to analytical difficulties. Other minor element abundances in C9872 do not seem to be unusual for Nyiragongo magmas. Th and $U$ are the only elements among those measured which can be correlated with the unusual radiogenic $\mathrm{Pb}$ in $\mathrm{C} 9872$.

Nyiragongo nephelinites are enriched in $h y g$ elements relative to Hawaiian nephelinites: $\mathrm{Rb}$, $\mathrm{K}$, Ta and $\mathrm{Nb}$ by $4-500 \%$ and other trace elements, with decreasing incompatibility, by $100 \%-30 \%$.

\section{Mineralogy}

Clinopyroxene is the dominant mafic silicate. Under the microscope it occurs as pale pink

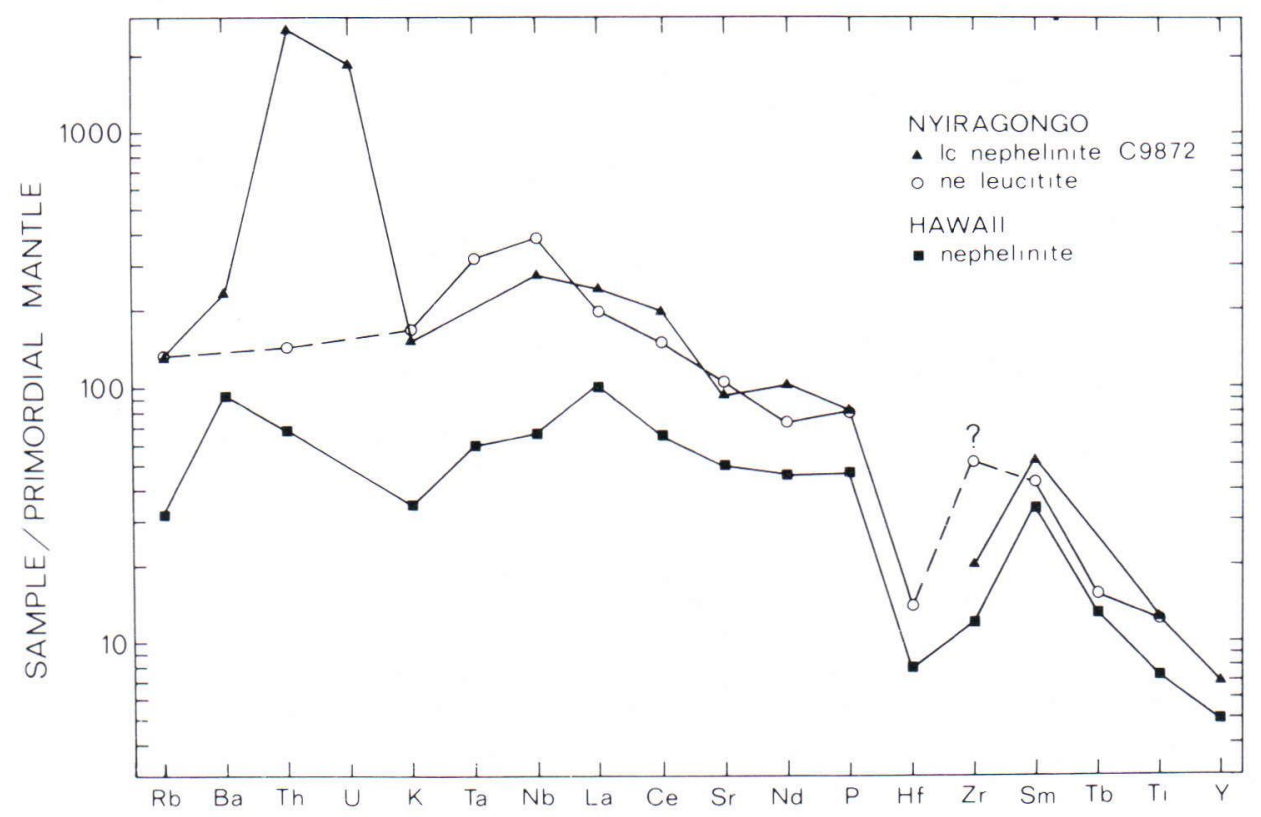

Fig. 5. Hyg-element abundance patterns normalized to estimated primordial mantle abundances (Wood et al., 1979) for leucite-nephelinite C9872 and a nephelinite-leucitite from Nyiragongo compared with a Hawaiian nephelinite (68PB-2: Clague and Frey 1982). Ne-leucitite concentrations are for C3023 (Mitchell and Bell 1976; Bell and Doyle 1971) except for P and $\mathrm{Ti}$ which are average Nyiragongo leucitite abundances (Bell and Powell 1969). $\mathrm{Zr}$ could be in error. 
subhedral to euhedral phenocrysts with zoning, and rather paler anhedral grains in the groundmass. The phenocrysts are $\mathrm{Al}$ and $\mathrm{Ti}$ rich salites with iron enriched rims as recorded by Sahama $(1976,1978)$ in nephelinites from the Nyiragongo main cone. The groundmass clinopyroxenes include varieties poorer in $\mathrm{Al}$ and $\mathrm{Ti}$ (Table 1) but considerably iron enriched (ferrosalites).

Leucite composition corresponds to almost the pure $\mathrm{KAlSi}_{2} \mathrm{O}$ end-member with little or no sodium. Traces of calcium attributed to apatite impurity by Sahama (1978) may be real.

Nepheline also contains traces of this element (one analysis with over $2 \% \mathrm{CaO}$ remains to be checked). The potassic nature of the nephelines in the Goma nephelinite (Bowen and Ellestad 1936) is confirmed although the $\mathrm{K}_{2} \mathrm{O}$ level is less than that quoted by these authors and by Sahama (1978) for the Nyiragongo main cone ( $\mathrm{K}_{2} \mathrm{O}$ range $11.1-12.7 \mathrm{wt} \%$ ). Although leucite and nepheline are clear in thin section both minerals are traversed by randomly oriented laths and needles of clinopyroxene and apatite respectively. Some of these could possibly be melilite but this mineral was not confirmed with the microprobe.

Small groundmass olivine microphenocrysts proved to be of a very unusual composition, corresponding to calcium fayalite, or more strictly, calcium ferro-hortonolite, since $\mathrm{Fa}=$ $86 \%$. Sahama (1978) has reviewed the olivine data from the Nyiragongo main cone. Here the olivines of the forsterite - fayalite series vary around $\mathrm{Fa}=20 \%$ ! In addition, he describes olivines of the monticellite-kirschsteinite series mostly enriched in the kirschsteinite end-member, $\mathrm{CaFeSiO}_{4}$, which are not known from elsewhere.

An unknown sodium iron silicate enriched in barium occurs in the groundmass.

Spinel is an abundant constituent both as phenocrysts and granules scattered through the groundmass. The analysis corresponds to a solid solution of $69 \%$ magnetite, with some addi- tional ions mainly $\mathrm{Al}$, and $31 \%$ ulvospinel with a little Si.

Perovskite was not found.

\section{Assimilation and metasomatism}

In the classical assimilation hypothesis of Holmes, the melilite leucite nephelinites of Goma are regarded as being close to the hypothetical magma "X» which, when it has »invaded, disintegrated and partially transfused and assimilated» biotite pyroxenite and peridotite, gives rise to more potassic and mafic types of lavas (Holmes and Harwood 1937, p. 81-83).

In modern terms, phlogopite (biotite)-pyroxenite and -peridotite equate with metasomatised mantle with nephelinite being a partial melt thereof. It appears that late, high-level metasomatism, in particular of $\mathrm{Fe}$, has also played a role. Sahama (1978) has demonstrated that during $\mathrm{Fe}$ metasomatism melilite breaks down to nepheline plus olivine of magnesium bearing kirschsteinite $\left(\mathrm{CaFeSiO}_{4}\right)$ composition. In our specimen, metasomatism appears to have been more extreme with the formation of calcium bearing fayalite $\left(\mathrm{Fe}_{2} \mathrm{SiO}_{4}\right)$ and groundmass ferrosalite. With the breakdown of melilite, perovskite seems also to disappear.

Possible phases to host $\mathrm{U}, \mathrm{Th}$ and radiogenic $\mathrm{Pb}$ include the minerals normally found in carbonatites and associated rocks: perovskite, pyrochlore $(\mathrm{Na}, \mathrm{Ca})_{2} \mathrm{Nb}_{2} \mathrm{O}_{6}(\mathrm{O}, \mathrm{OH}, \mathrm{F}) \pm \mathrm{U}$, monazite ( \pm REE, Th) and zircon/baddeleyite. These either remained undetected or have been resorbed and destroyed during high-level Fe metasomatism. In the latter case, $\mathrm{U}, \mathrm{Th}$ and radiogenic $\mathrm{Pb}$ should now be found on grain boundaries. The undisturbed $\mathrm{U}-\mathrm{Th}-\mathrm{Pb}$ systematics for rock C9872 (see above) would then imply that these three elements were neither added nor lost in this process.

A close relationship between nephelinites and carbonatites in east and central Africa has been summarised by LeBas (1977) who suggested that it may be due to silicate/carbonate liquid 
unmixing during upward movement of a parental carbonatitic olivine nephelinite magma. The extent to which this process may have operated in the Nyiragongo field is unknown. At least three rift-associated carbonatite centres occur to the north of this field (Lueshe, Fort Portal and Bwera, a new discovery south of Ruwenzori - J. D. Lytham, personal communication). Lueshe is an eroded centre of greater age than the recent Nyiragongo lavas. Clearly there could be other carbonatites beneath Nyiragongo which have contributed $U$ and $T h$ to the nephelinite magmas.

It is possible that ca. $500 \mathrm{Myr}$ ago, beneath Nyiragongo, both silicate and carbonatite magma fractions evolved. There is some evidence from abundant groundmass carbonate in melilite nephelinites (Sahama 1978) that unmixing was incomplete. Within the Goma nephelinite, however, there is very little carbonate and, if originally present, it must have been evolved as $\mathrm{CO}_{2}$ forming the observed vesicular texture or have been destroyed during the high level $\mathrm{Fe}$ metasomatism event.

\section{References}

Allègre, C. J.; Dupré, B.; Lambret, B. \& Richard, P., 1981. The subcontinental versus suboceanic debate, I. Leadneodymium-strontium isotopes in primary alkali basalts from a shield area: the Ahaggar volcanic suite. Earth Planet. Sci. Lett. 52, 85-92.

Bailey, D. K., 1977. Lithosphere control of continental rift magmatism. J. geol. Soc. Lond. 133, 103-106.

Bailey, D. K., 1980. Volatile flux, geotherms, and the generation of the kimberlite-carbonatite-alkaline magma spectrum. Mineral. Mag. 43, 695-699.

Bailey, D. K., 1982. Mantle metasomatism - continuing chemical change within the Earth. Nature 296, 525-530.

Bell, K. \& Doyle, R. J., 1971. K-Rb relationships in some continental alkalic rocks associated with the East African Rift valley system. Geochim. Cosmochim. Acta 35, 903-915.

Bell, K. \& Powell, J. L., 1969. Strontium isotopic studies of alkalic rocks: the potassium-rich lavas of the Birunga and Toro-Ankole regions, east and central equatorial Africa. J. Petrol. 10, 536-572.
$\mathrm{Pb}$ isotope data for east African carbonatites (Lancelot and Allègre 1973) support such a connection: ${ }^{206} \mathrm{~Pb} /{ }^{204} \mathrm{~Pb}$ and ${ }^{207} \mathrm{~Pb} /{ }^{204} \mathrm{~Pb}$ ratios are very similar to the range of less radiogenic Nyiragongo compositions although ${ }^{208} \mathrm{~Pb} /{ }^{204} \mathrm{~Pb}$ ratios are lower implying a source evolution with Th/U less than 5 (see Fig. 4 in Vollmer and Norry, 1983 b).

In conclusion, our evidence suggests that carbonatite-related minerals of the kind mentioned above were incorporated into the nephelinite magma and remained stable possibly until broken down during the late high-level Fe metasomatism event. Carbonatite itself or a carbonatite precursor can reasonably be regarded as a result of mantle metasomatism. Therefore our data support the conclusion of Vollmer and Norry (1983 a) that the radiogenic $\mathrm{Pb}$ of $\mathrm{C} 9872$ dates a ca. 500 Myr old metasomatic event in the mantle.

Acknowledgements. We thank S. O. Agrell for a sample of C9872 and A. Grey and H.-U. Schmincke for chemical analyses.

Bowen, N. L. \& Ellestad, R. B., 1936. Nepheline contrasts. Amer. Miner. 21, 363-368.

Cahen, L., 1970. Igneous activity and mineralisation episodes in the evolution of the Kibaride and Katangide orogenic belts of Central Africa. In: Clifford, T. N. and Gass, I. G. (Editors) African magmatism and tectonics. Oliver \& Boyd. Edinburgh. 97-117.

Chauvel, C. \& Jahn, B.-M., 1984. Nd-Sr isotope and REE geochemistry of alkali basalts from the Massif Central, France. Geochim. Cosmochim. Acta 48, 93-110.

Clague, D. A. \& Frey, F. A., 1982. Petrology and trace element geochemistry of the Honolulu volcanics, Oahu: implications for the oceanic mantle below Hawaii. J. Petrol. 23, 447-504.

Erlank, A. J.; Allsopp, H. L.; Hawkesworth, C. J. \& Menzies, M. A., 1982. Chemical and isotopic characterisation of upper mantle metasomatism in peridotite nodules from the Bultfontein kimberlite. Terra cognita 2, 261263.

Frey, F. A.; Green, D. H. \& Roy, S. D., 1978. Integrated models of basalt petrogenesis: A study of quartz tholeiites to olivine melilitites from south eastern Australia utilizing 
geochemical and experimental petrological data. J. Petrol. $19,463-513$.

Holmes, A. \& Harwood, H. F., 1937. The volcanic area of Bufumbira: the petrology of the volcanic aea of Bufumbira. Mem. Geol. Surv. Uganda 3, Part II.

Irwing, A. J., 1978. A review of experimental studies of crystal/liquid trace element partitioning. Geochim. Cosmochim. Acta 42, 743-770.

Kay, R. W. \& Gast, P. W., 1973. The rare earth content and origin of alkali-rich basalts. J. Geol. 81, 653-682.

Lancelot, J. R. \& Allègre, C. J., 1974. Origin of carbonatitic magma in the light of the $\mathrm{Pb}-\mathrm{U}-\mathrm{Th}$ isotope system. Earth Planet. Sci. Lett. 22, 233-238.

LeBas, M. J., 1977. Carbonatite - nephelinite volcanism. John Wiley \& Sons. London. 347 pp.

Lloyd, F. E. \& Bailey, D. K., 1975. Light element metasomatism of the continental mantle: the evidence and consequences. Phys. Chem. Earth 9, 389-416.

Menzies, M. \& Murthy, R. V., 1980. Nd and Sr isotope geochemistry of hydrous mantle nodules and their host alkali basalts: implications for local heterogeneities in metasomatically veined mantle. Earth Planet. Sci. Lett. 46, 323-334.

Menzies, M. A.; Leeman, W. P. \& Hawkesworth, C. J., 1983. Isotope geochemistry of Cenozoic volcanic rocks reveals mantle heterogeneity below western USA. Nature 303, 205-209.

Mitchell, R. H. \& Bell, K., 1976. Rare earth element geochemistry of potassic lavas from the Birunga and ToroAnkole regions of Uganda, Africa. Contrib. Mineral. Petrol. 58, 293-303.

Morgan, W. J., 1971. Convection plumes in the lower mantle. Nature 230, 42-43.
Sahama, Th. G., 1961. Thermal metamorphism of the volcanic rocks of Mt. Nyiragongo (Eastern Congo). C. R. Soc. Geol. Finlande 33, 151-174.

Sahama, Th. G., 1976. Composition of clinopyroxene and melilite in the Nyiragongo rocks. Carnegie Inst. Year Book 75, 585-591.

Sahama, Th. G., 1978. The Nyiragongo main cone. Ann. Musée roy. Afrique Centrale, Tervuren (Belgique), sér. in- $8^{\circ}$, Sci. géol. $81,88 \mathrm{pp}$.

Sun, S. S. \& Hanson, G. N., 1975. Origin of Ross Island basanitoites and limitations upon the heterogeneity of mantle sources for alkali basalts and nephelinites. Contrib. Mineral. Petrol 52, 77-106.

Tatsumoto, M., 1978. Isotopic composition of lead in oceanic basalts and its implication to mantle evolution. Earth Planet. Sci. Lett. 38, 63-87.

Vollmer, R., 1983. Earth degassing, mantle metasomatism and isotopic evolution of the mantle. Geology 11, 452454.

Vollmer, R. \& Norry, M. J., 1983 a. Unusual isotopic variations in Nyiragongo nephelinites. Nature 301, 141-143.

Vollmer, R. \& Norry, M. J., 1983 b. Possible origin of K-rich volcanic rocks from Virunga, East Africa, by metasomatism of continental crustal material: $\mathrm{Pb}, \mathrm{Nd}$ and Sr isotopic evidence. Earth Planet. Sci. Lett. 64, 374-386.

Wass, S. Y. \& Rogers, N. W., 1980. Mantle metasomatism - precursor to continental alkaline volcanism. Geochim. Cosmochim. Acta 44, 1811-1823.

Wood, D. A.; Joron, J.-L.; Treuil, M.; Norry, M. \& Tarney, J., 1979. Elemental and $\mathrm{Sr}$ isotope variations in basic lavas from Iceland and the surrounding ocean floor. Contrib. Mineral. Petrol. 70, 319-339. 